九州大学学術情報リポジトリ

Kyushu University Institutional Repository

\title{
Hypersensitive Reaction of Cowpea Leaf to Infiltration of Xanthomonas campestris pv. Oryzae
}

Tsuchiya, Kenichi

Laboratory of Plant Pathology, Faculty of Agriculture, Kyushu University

Mew, Twng-Wah

The International Rice Research Institute (IRRI)

Wakimoto, Satoshi

Laboratory of Plant Pathology, Faculty of Agriculture, Kyushu University

https://doi.org/10.5109/23772

出版情報 : 九州大学大学院農学研究院紀要. 27 (3/4), pp. 189-195, 1983-02. Kyushu University バージョン：

権利関係 : 


\title{
Hypersensitive Reaction of Cowpea Leaf to Infiltration of Xanthomonas campestris pv. oryzae
}

\author{
Kenichi Tsuchiya, Twng-Wah Mew* \\ and Satoshi Wakimoto \\ Laboratory of Plant Pathology, Faculty of Agriculture, \\ Kyushu University 46-01, Fukuoka 812 \\ (Received October 22, 1982)
}

\begin{abstract}
By infiltration with both wild type strains and virulent $N$-methyl- $N^{\prime}$-nitro- $N$-nitrosoguanidine (NTG)-induced mutants of Xanthomonas campestris pv. oryzae cowpea leaf tissues produced necrosis within $24 \mathrm{hr}$, which could be designated as typical hypersensitive reaction (HR). Among fractions of bacterial culture tested, only living bacterial cells were effective for necrosis inductivity, while heat-killed cells, culture filtrate and extracellular polysaccharide were ineffective. HR was induced at a concentration level higher than ca. $10^{7}$ cells $/ \mathrm{ml}$ of virulent bacteria, while neither necrosis nor yellowish discoloration developed with the bacteria below $10^{4}$ cells/ml. Avirulent mutant strains did not induce necrosis in cowpea leaf even at a concentration higher than $10^{7}$ cells $/ \mathrm{ml}$, while the virulent revertant regained the necrosis inductivity associating with the restoration of virulence.
\end{abstract}

\section{INTRODUCTION}

The hypersensitive reaction (HR) is known to be one of the most important defense reaction of plants in incompatible host-pathogen combination. Since the first report of HR concerning with pseudomonads-tobacco combination (Klement et al., 1964). the phenomenon has been confirmed to occur with various host-bacteria combinations such as tobacco plant against Pseudomonas syringae or Erwinia amylovora (Klement and Goodman, $1967 \mathrm{~b}$ ), apple tree against E. amylovora (Burkowicz and Goodman, 1969), pepper against Xanthomonas campestris pv. vesicatoria (Cook and Stall, 1971), bean plants against P. phaseolicola (Smith and Mansfield, 1981) and so on. Among them, some reports focused on the correlation between pathogenicity or virulence and HR (Averre and Kelman, 1964; Klement and Goodman, 1966, 1967 a; Lozano and Sequeira, 1970; O'Brien and Wood, 1973; Turner and Novacky, 1974).

In connection with $\mathrm{X}$. campestris pv. oryzae, some host responses observed in resistant rice variety or uncongenial plant were referred to as HR (Cook, 1971; Horino, 1976; Kaku and Hori, 1977).

In the present study, the reaction of cowpea leaf tissues infiltrated with wild types and $N$-methyl- $N^{\prime}$-nitro- $N$-nitrosoguanidine (NTG)-induced mutant strains of $\mathrm{X}$. campestris pv. oryzae was investigated with particular attention to

* The International Rice Research Institute (IRRI), Los Baños, Laguna, Philippines. 
the relationship between intensity or characteristics of $\mathrm{HR}$ and virulence of the bacterium.

\section{MATERIALS AND METHODS}

\section{Bacterial strains and test plant}

Four wild type strains of X. campestris pv. oryzae, PXO 61, PXO 63-6, PX079 and PX071, which belong to different pathogenic groups in the Philippines, I, II, III and IV, respectively, were used. These bacterial cultures were supplied from the stock cultures maintained in the Department of Plant Pathology, the International Rice Research Institute (IRRI). Besides, two parent strains, PXO 61 PT and PXO 63-6PT, and NTG-induced mutant strains with various phenotypes (Tsuchiya et al., 1982) were also used.

Cowpea plant (Vigna unguiculata (L.) Wal. var. EG\# 2) was grown for about 2 weeks under ordinary greenhouse conditions (temp. $25-30^{\circ} \mathrm{C}$ ) and the fully expanded primary leaves were used for infiltration.

\section{Inoculum preparation and infiltration to leaf tissue}

Each bacterial strain was grown in peptone-sucrose broth (PSB) medium containing $10 \mathrm{~g}$ peptone, $10 \mathrm{~g}$ sucrose and $1 \mathrm{~g}$ sodium glutamate, in $1,000 \mathrm{ml}$ distilled water, $\mathrm{pH} 7.0$, at $30^{\circ} \mathrm{C}$ for $48 \mathrm{hr}$ in shake culture. Cells were washed twice by centrifugation $(10,000 \times g, 20 \mathrm{~min})$, then resuspended in sterile distilled water at an approximate concentration of $10^{9}$ cell $\mathrm{s} / \mathrm{ml}$. Leaf was pin-pricked at a site to be infiltrated, subsequently bacterial suspension was infiltrated into the intercellular spaces through wound with a hypodermic syringe (Fig. 1-A). To get informations concerning the facfors responsible for induction of necrosis bacterial culture of a virulent strain, PXO $61 \mathrm{PT}$, was fractionated and infiltrated. Forty eight-hr-old liquid culture of PXO 61PT was washed twice by cen. trifugation and resuspended bacteria was used as living whole cell fraction. Besides the living whole cells, heat-killed cells, culture filtrate, dialized culture filtrate and crude extracellular polysaccharide (EPS) were also served for infiltration. For preparing heat-killed cells, washed bacterial suspension in distilled water (ca. $10^{9}$ cells $/ \mathrm{ml}$ ) was treated at 60 or $100^{\circ} \mathrm{C}$ for $10 \mathrm{~min}$ in a water bath. Crude EPS solution was prepared as follows. Three volumes of 95 cold ethanol were slowly added to $500 \mathrm{ml}$ of bacterial culture filtrate with stirring. The precipitate was recovered by centrifugation at $8,000 \times g$ for 30 min and twice with $95 \%$ ethanol. After ethanol was removed by vacuum evaporation at $60^{\circ} \mathrm{C}$ EPS was finally dissolved in $25 \mathrm{ml}$ of water and it was served as an inoculum. Infiltrated leaves were observed periodically up to $96 \mathrm{hr}$ after infiltration under the greenhouse conditions.

\section{RESULTS}

\section{Leaf reactions to bacterial infiltration}

Leaf areas infiltrated with ca. $10^{9}$ cell $\mathrm{s} / \mathrm{ml}$ suspensions of virulent wild 
type strains were water-soaked, showing vellowish discoloration and slight chlorosis by 8 to $12 \mathrm{hr}$ after infiltration. Within $24 \mathrm{hr}$ brown necrosis resembled to HR was induced and then those areas were withered and dried (Fig. 1-B and Table 1). Such reaction was induced similarly regardless of pathogenic group of the bacteria.

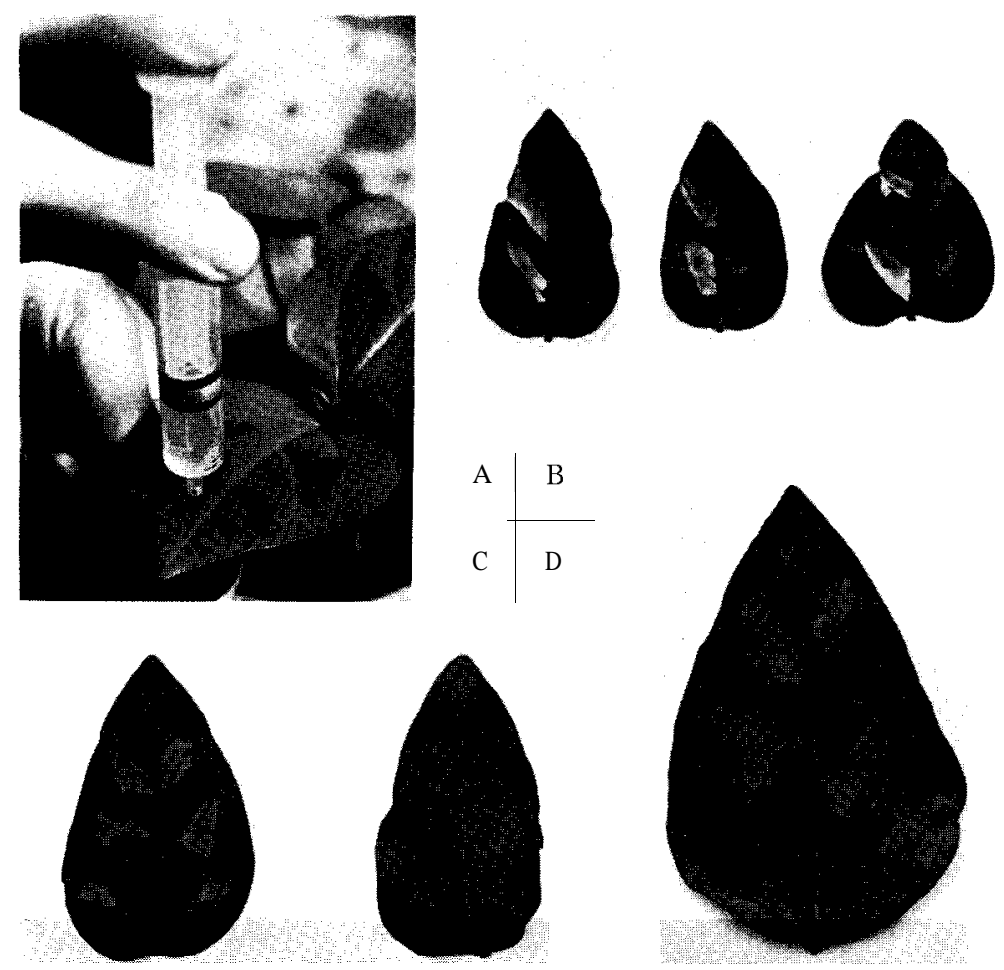

Fig. 1. (A) Infiltration method. (B) Reactions of cowpea leaf tissue to virulent strain (left halves) and avirulent mutant strain (right halves), from the left 24, 72 and $96 \mathrm{hr}$ after infiltration, respectively. (C) Reactions of cowpea leaf tissue to living whole cell (left) and heat-killed bacteria (right) $24 \mathrm{hr}$ after infiltration. (D) Reaction of cowpea leaf tissue to parent strain (left half) and white colony mutant strain (right half) $48 \mathrm{hr}$ after infiltration.

On the other hand, infiltration with avirulent strains such as PX061 NT 3 and PX061 NT 3 RV-1 usually induced no response or yellowing within $48 \mathrm{hr}$ at the infiltrated areas, but necrosis was not induced. These areas occasionally became brownish yellow later on but did not develop to the same symptom as shown by virulent strains (Fig. 1-B). The virulent revertant, PXO 61 NT 3 $\mathrm{RV}-2$, which was induced from an avirulent mutant, regained necrosis inductivity similar to the parent strain (Table 1 ).

PXO 63-6 NT 5 (weakly virulent mutant) and PXO 63-6 NT 8 (virulent mu- 
tant with white colony) also induced necrosis at the infiltrated areas, though the host reaction was somewhat slow and weak with the former (Table 1 and Fig. I-D).

Table 1. Reactions of cowpea leaf tissue to infiltration with different strains of X. campestris pv. oryzae.

\begin{tabular}{|c|c|c|c|c|c|}
\hline \multirow{2}{*}{ Bacterial strain } & \multirow{2}{*}{ Phenotype ${ }^{2)}$} & \multicolumn{2}{|c|}{ Period after } & \multicolumn{2}{|c|}{ infiltration (hr) } \\
\hline & & 12 & 24 & 48 & 96 \\
\hline \multicolumn{6}{|l|}{ Wild type } \\
\hline PXO61 $\quad(\mathrm{I})^{1}$ & $\mathrm{~V}$ & $(\mathrm{Y})^{3)}$ & it & $-H_{1}$ & . It \\
\hline PXO63-6 (II) & $\mathrm{V}$ & (Y) & $H$ & H & t \\
\hline PXO79 (III) & $\mathrm{V}$ & $(\mathrm{Y})$ & t & $+t$ & +4 \\
\hline PX071 (IV) & $\mathrm{V}$ & $(Y)$ & H. & H & H \\
\hline \multicolumn{6}{|l|}{ Parent } \\
\hline PX061PT & V & $(\mathrm{Y})$ & H & $-t$ & H \\
\hline PX063-6P'T & V & (Y) & H & \# & $\ddot{H}$ \\
\hline \multicolumn{6}{|l|}{ NTG-induced mutant } \\
\hline PX061NT3 & $\mathrm{AV}, \mathrm{w}$ & $(\mathrm{Y})$ & $\mathrm{Y}$ & $\mathrm{Y}$ & $\mathrm{Y}$ or $\mathrm{BY}$ \\
\hline PX061NT3RV-1 & A V & (Y) & Y & $\mathrm{Y}$ & Y or BY \\
\hline PXO61NT3RV-2 & $\mathrm{V}$ & $(\mathrm{Y})$ & $-t+$ & + & it \\
\hline PX063-6NT5 & $\begin{array}{l}\text { WV } \\
\text { V W }\end{array}$ & (Y) & + & & -tt \\
\hline PX063-6NT8 & $\mathrm{V}, \mathrm{W}$ & (Y) & H & tt & 4 \\
\hline
\end{tabular}

\section{Effect of bacterial concentration on HR induction}

To determine the critical concentration of bacteria for necrosis inductivity, bacterial suspension of both virulent and avirulent strains were serially diluted

Table 2. Reactions of cowpea leaf tissue to infiltration with different concentration of bacteria.

\begin{tabular}{|c|c|c|c|c|}
\hline \multirow{2}{*}{ Bacterial strain (original conc.) } & \multirow{2}{*}{$\begin{array}{c}\text { Serial } \\
\text { dilution }\end{array}$} & \multicolumn{3}{|c|}{ Period after infiltration (hr) } \\
\hline & & 24 & 48 & 96 \\
\hline PX061PT (V) $\left(2.0 \times 10^{9} \mathrm{cells} / \mathrm{ml}\right)$ & $\begin{array}{l}10^{0} \\
10^{-2} \\
10^{-3} \\
10^{-4} \\
10^{-5}\end{array}$ & $\begin{array}{l}H^{11} \\
+ \\
- \\
-\end{array}$ & $\begin{array}{l}+ \\
+ \\
(\mathrm{Y}) \\
(\mathrm{Y}) \\
-\end{array}$ & $\begin{array}{c}+ \\
+ \\
+(Y) \\
(Y) \\
-\end{array}$ \\
\hline PXO61NT3 (AV) $(5.1 \times 109$ cells/ml) & $\begin{array}{l}10^{0} \\
10^{-2} \\
10^{-3} \\
10^{-4} \\
10^{-5}\end{array}$ & $\begin{array}{c}\mathrm{Y} \\
(\mathrm{Y}) \\
-\end{array}$ & $\begin{array}{c}\mathrm{Y} \\
\mathrm{Y} \\
(\mathrm{Y})\end{array}$ & $\begin{array}{c}\mathrm{Y} \text { or } \mathrm{BY} \\
\mathrm{Y} \text { or } \mathrm{BY} \\
\text { (Y) }\end{array}$ \\
\hline PX061NT3RV-2 (V) $\left(3.8 \times 10^{9}\right.$ cells $\left./ \mathrm{ml}\right)$ & $\begin{array}{l}10^{0} \\
10^{-2} \\
10^{-3} \\
10^{-4} \\
10^{-5}\end{array}$ & $\begin{array}{l}+t \\
+ \\
- \\
-\end{array}$ & $\begin{array}{l}+ \\
+ \\
(Y)\end{array}$ & $\begin{array}{c}H \\
+ \\
Y \\
(Y)\end{array}$ \\
\hline
\end{tabular}

1) See Table 1. 
and infiltrated into cowpea leaf tissue, respectively. The distinct necrosis was induced at the infiltrated areas with virulent strain at a concentration higher than ca. $10^{7}$ cells $/ \mathrm{ml}$ by $24 \mathrm{hr}$ after infiltration. At a concentration of ca. $10^{6}$ cells $/ \mathrm{ml}$, however, the infiltrated areas showed discoloration but not necrosis. No visible response occurred when bacterial concentration was below $10^{4}$ cells/ ml (Table 2). With avirulent strain, PXO 61 NT3 or PXO61 NT3 RV-1, infiltration did not induce necrosis until $\mathbf{4 8} \mathrm{hr}$ after infiltration and the affected areas remained yellow even at a concentration higher than $10^{9}$ cells $/ \mathrm{ml}$ (Table 2).

\section{Reaction of cowpea leaf tissue to infiltration with various inoculum preparation}

Among preparations infiltrated in this experiment, only the fractions containing living cells induced necrosis and none of heat-killed cells, culture filtrate and EPS had critical effect for necrosis inductivity (Fig. 1-C and Table 3).

Table 3. Factors necessary for inciting hypersensitive reaction in cowpea leaf tissue.

\begin{tabular}{lc}
\hline \multicolumn{1}{c}{ Inoculum infiltrated } & $\begin{array}{c}\text { Reaction of cowpea leaf tissue } \\
\text { (3 days }\end{array}$ \\
\hline after infiltration $)$
\end{tabular}

1) See Table 1.

\section{DISCUSSION}

Since Klement et al. (1964) reported HR caused by phytopathogenic bacteria, many workers have studied on this phenomenon in connection with its mechanisms from the viewpoints of physiological and ultrastructural changes (Klement and Goodman, 1967 a, b; Huang and Goodman, 1970; Novacky, 1972 ; O'Brien and Wood, 1973; Sigee and Epton, 1976; Roebuck et al., 1978). Furthermore, several workers have studied HR in connection with virulence of bacteria by using virulent strains and avirulent mutants (Averre and Kelman, 1964 ; Klement and Goodman, 1966; Burkowicz and Goodman, 1969; Loaano and Sequeira, 1970 ; Stall et al., 1974). Regarding the relationship between virulence and HR inductivity in incompatible host-bacteria combination, some workers reported that avirulent mutant also induced HR as well as virulent strains (Averre and Kelman, 1964; Klement and Goodman, 1966). Lozano and Sequeira (1970), on the other hand, reported that HR inductivity of avirulent mutants was either positive or negative depending upon the strains.

In the present study, when cowpea, an uncongenial test plant, was infiltrated with high concentration (more than $10^{7}$ cells $/ \mathrm{ml}$ ) of virulent strains of $\mathrm{X}$. 
campestris pv. oryzae, necrosis was induced at the infiltrated leaf area by $24 \mathrm{hr}$ after infiltration. This necrosis could be considered as the results of HR which was reported by other combinations of bacteria and incompatible plants. Because, the host response against $\mathrm{X}$. campestris pv. oryzae satisfies the primary conceptions of $\mathrm{HR}$, that is, leaf reactions were generally developed rapidly to induce necrosis within $24 \mathrm{hr}$, and the necrosis associating with withering or drying were induced by only living bacterial cells at a concentration higher than $10^{7}$ cells/ml (Klement et al., 1964; Klement and Goodman, 1967 b; Roebuck et al., 1978).

Inductivity of $\mathrm{HR}$ in cowpea leaf tissues was quite different depending upon virulence of infiltrated bacteria, namely, rapid necrosis was induced with virulent strain within $24 \mathrm{hr}$ after infiltration and withered later on, while no response or sometimes yellowish discoloration was induced with avirulent strain. In the latter case, brownish yellowing was occasionally developed later but its appearance was quite different from the response shown in the former. Virulent with white colony mutant, PXO 63-6 NT 8, also induced HR as well as parent strain. All of the virulent wild type strains and some virulent mutants with different phenotypes induced by NTG were positive in HR inductivity so far as tested, suggesting close correlation between virulence of this bacterium to rice and $\mathrm{HR}$ inductivity in cowpea.

\section{REFERENCES}

Averre, C. W. and A. Kelman 1964 Severity of bacterial wilt as influenced by ratio of virulent to avirulent cells of Pseudomonas solanacearum in inoculum. Phytopathology, 54: 779-783

Burkowicz, A. and R. N. Goodman 1969 Permeability alterations induced in apple leaves by virulent and avirulent strains of Erwinia amylovora. Phytopathology, 59: 314-358

Cook, A. A. 1971 Alteration of hypersensitivity in plants to bacterial infection. Proc. 3 rd Internat. Conf. Plant Pathogenic Bacteria, Wageningen: 171-178

Cook, A. A. and R. E. Stall 1971 Calcium suppression of electrolyte loss from pepper leaves inoculated with Xanthomonas vesicatoria. Phytopathology, 61 : 484-487

Horino, 0. 1976 Induction of bacterial leaf blight resistance by incompatible strains of Xanthomonasoryzae in rice. In "Biochemistry and Cytology of Plant-Parasite Interaction", ed. by K. Tomiyama et al., Kodansha Ltd., pp. 43-45

Huang, J. S. and R. N. Goodman 1970 The relationship of phosphatidase activity to the hypersensitive reaction in tobacco induced by bacteria. Phytopathology, 60: 1020-1021

Kaku, H. and M. Hori 1977 Browning reaction in rice plant tissues induced hy Xanthomonas oryzae. Ann. Phytopath. Soc. Japan, 43: 487-490

Klement, Z., G. L. Farkas and L. Lovrekovich 1964 Hypersensitive reaction induced by phytopathogenic bacteria in the tobacco leaf. Phytopathology, 54: 471-477

Klement, Z, and R. N. Goodman 1966 Hypersensitive reaction induced in apple shoots by an avirulent form of Erwinia amylovora. Acta Phytopathol. Hung., 1: 177-184

Klement, Z. and R. N. Goodman 1967a The hypersensitive reaction to infection by bacterial plant pathogens. Ann. Rev. Phytopath., 5: 17-44

Klemcnt, Z. and R. N. Goodman $1967 \mathrm{~b}$ The role of the living bacterial cell and induction time in the hypersensitive reaction of the tobacco plant. Phytopathology, 57: 322323 
Lozano, J. C. and L. Sequeira 1970 Differentiation of races of Pseudomonas solanacearum by a leaf infiltration technique. Phyfopathology, 60: 833-838

Novacky, A. 1972 Suppression of the bacterially induced hypersensitive reaction by cytokinins. Physiol. Plant Pathol., 2: 101-104

O'Brien, F. and R. K. S. Wood 1973 Role of ammonia in infection of Phaseolus vulgaris by Pseudomonas spp. Physiol. Plant Pathol., 3: 315-325

Roebuck, P., R. Sexton and J. W. Mansfield 1978 Ultrastructural observations on the development of the hypersensitive reaction in leaves of Phaseolus vulgaris cv. Red Mexican inoculated with Pseudomonas phaseolicola (race 1). Physiol. Plant Pathol., 12: 151-157

Sigee, D. C. and H. A. S. Epton 1976 Ultrastructural changes in resistant and susceptible varieties of Phaseolus vulgaris following artificial inoculation with Pseudomonasphaseolicola. Physiol. Plant Pathol,,9:1-8

Smith, J. J. and J. W. Mansfield 1981 Interactions between pseudomonads and leaves of oats, wheat and barley. Physiol. Plant Pathol., 18: 345-356

Stall, R. E., J. A. Bartz and A. A. Cook 1974 Decreased hypersensitivity to xanthomonads in pepper after inoculations with virulent cells of $\mathbf{X}$ anthomonas vesicatoria. Phytopathology, 64: $731-735$

Tsuchiya, K., T. W. Mew and S. Wakimoto 1982 Bacteriological and pathological characteristics of wild types and induced mutants of $\mathbf{X}$ anthomonas campestris pv. oryzae. Phytopathology, 72: 43-46

Turner, J. G. and A. Novacky 1974 The quantitative relation between plant and bacterial cells involved in the hypersensitive reaction. Phytopathology, 64: 885-890 